\title{
Genetic merit for fertility traits in Holstein cows: IV. Transition period, uterine health, and resumption of cyclicity
}

\author{
S. G. Moore,${ }^{\star} †$ T. Fair, $†$ P. Lonergan, $\dagger$ and S. T. Butler ${ }^{* 1}$ \\ *Animal and Grassland Research and Innovation Centre, Teagasc, Moorepark, Fermoy, Co. Cork, Ireland \\ †School of Agriculture and Food Science, University College Dublin, Belfield, Dublin 4, Ireland
}

\begin{abstract}
The objective of this study was to monitor the dry matter intake (DMI), metabolic status, uterine health, and resumption of cyclicity in cows with similar genetic merit for milk production traits but with either good (Fert+) or poor genetic merit (Fert-) for fertility traits. Twenty-six cows were enrolled in the study and data are reported for 15 Fert+ and 10 Fert- cows that completed the study. All cows received a total mixed ration diet during early lactation and were turned out to pasture in late spring. Dry matter intake was recorded daily from wk -2 to 5 relative to parturition. Blood metabolites and metabolic hormones were measured from wk -2 to 8 relative to parturition. Milk production, body condition score, and body weight until wk 35 of lactation are reported. To monitor uterine health, vaginal mucus was scored weekly on a scale of 0 (no pus) to 3 ( $\geq 50 \%$ pus) from parturition to wk 8 and uterine polymorphonuclear neutrophil count was measured at wk 3 and 6 postpartum. Prepartum DMI was similar between genotypes, but Fert+ cows had significantly greater DMI than Fert- cows (19.7 vs. 16.8 $\mathrm{kg}$ of dry matter/d) during the postpartum period. Energy balance at wk 1 was significantly greater in Fert+ cows than in Fert- cows [2.3 vs. - 1.12 unité fourragère lait (UFL)/d]. The Fert+ cows had significantly greater daily milk solids production (1.89 vs. $1.74 \mathrm{~kg} / \mathrm{d}$ ) and tended to have greater daily milk yield ( 24.2 vs. 22.3 $\mathrm{kg} / \mathrm{d}$ ). The Fert+ cows had significantly greater mean circulating insulin-like growth factor-I (102.62 vs. 56.85 $\mathrm{ng} / \mathrm{mL}$ ) and tended to have greater mean circulating insulin (3.25 vs. $2.62 \mu \mathrm{IU} / \mathrm{mL}$ ) compared with Fertcows from wk -2 to 8 relative to parturition. Mean circulating glucose (3.40 vs. $3.01 \mathrm{mmol} / \mathrm{L})$ concentrations were significantly greater in Fert+ cows compared with Fert- cows from wk -2 to 3 relative to parturition. The Fert+ cows maintained significantly greater mean body condition score throughout lactation compared
\end{abstract}

Received July 23, 2013.

Accepted January 23, 2014

${ }^{1}$ Corresponding author: stephen.butler@teagasc.ie with Fert- cows (2.98 vs. 2.74 units). Moreover, Fert+ cows had better uterine health compared with Fertcows, as evidenced by lower weekly vaginal mucus scores from wk 2 to 6 postpartum and, based on uterine cytology, smaller proportions were classified as having endometritis at wk 3 (0.42 vs. 0.78) and 6 (0.25 vs. $0.75)$. Also, a significantly greater proportion of Fert+ cows had resumed cyclicity by wk 6 postpartum $(0.86$ vs. 0.20) compared with Fert- cows. Hence, we report for the first time that genetic merit for fertility traits is associated with postpartum uterine health status. Superior uterine health and earlier resumption of cyclicity may be mediated through differences in DMI, energy balance, insulin, insulin-like growth factor-I, and body condition score profiles. Importantly, phenotypic improvement in fertility traits was achieved without antagonizing milk production.

Key words: genetic merit for fertility, transition period, dry matter intake, endometritis

\section{INTRODUCTION}

The transition period in cattle is described as the period from 3 wk precalving to 3 wk postcalving and is associated with the potential occurrence of a vast array of diseases that affect production, fertility, and health (Drackley, 1999). During this period, the energy requirements of the fetus and the mammary gland increase at a greater rate than energy intake. Typically, dairy cows enter a period of negative energy balance a few days before calving, reach nadir 2 wk later, and return to positive energy balance by wk 10 (Butler, 2003). Some of the adverse effects of negative energy balance on fertility are mediated by delays in resumption of cyclicity (Butler et al., 2006). After parturition, circulating glucose is prioritized for the mammary gland instead of peripheral tissues and adipose tissue is mobilized, resulting in NEFA and glycerol release from adipose tissue, and a decline in BCS. In the liver, NEFA can be (1) completely oxidized for energy, (2) partially oxidized to form ketones, or (3) esterified to form triglycerides, resulting in fatty liver (Ingvartsen, 2006). Concurrently, delayed recoupling of the somatotropic axis due to insufficient circulating insulin (Butler 
et al., 2003) increases the rate and duration of adipose tissue mobilization. Peripartum concentrations of these metabolites have been shown to be different in cows that do or do not ovulate the follicle from the first postpartum follicular wave (Butler et al., 2006), and also in cows that do or do not become pregnant to first AI (Garverick et al., 2013). In addition, circulating concentrations of NEFA, BHBA, and glucose have been incorporated into a model of "physiological imbalance" that is associated with the risk of disease during early lactation (Moyes et al., 2013). Also, early resumption of ovarian cyclicity following parturition is a key factor in determining subsequent fertility (Darwash et al., 1997; Galvão et al., 2010).

Positive effects of BCS on fertility have been reported in pasture and confinement dairy systems (Buckley et al., 2003; Roche et al., 2007; Santos et al., 2009). Attempts to minimize adipose tissue mobilization during the early postpartum period through altered nutritional and management strategies have had limited success in pasture-based systems (Horan et al., 2005a; Roche et al., 2006). However, it has been shown that BCS is under strong genetic control and that it differs between breeds and between strains within breed (Horan et al., 2005a; Friggens et al., 2007; Lucy et al., 2009; Prendiville et al., 2009; Cummins et al., 2012a; Heins et al., 2012).

It is generally accepted that all cows become exposed to bacteria after calving. The development of uterine disease depends on the type of bacteria involved and on the immune response of the cow and is associated with reduced subsequent fertility (Sheldon et al., 2009). Clinical disease, lower DMI, increased bacterial presence, and increased NEFA and BHBA concentrations during the transition period have been associated with the incidence of endometritis between 4 and 6 wk postpartum (LeBlanc, 2012).

We have previously validated a lactating Holstein cow genetic model of fertility (Cummins et al., 2012a) and used this animal model to identify some of the effects of genetic merit for fertility traits on phenotypic measures of fertility (Cummins et al., 2012a,b,c). The aim of the current study was to determine the effect of genetic merit for fertility traits on DMI, energy balance, blood indicators of metabolic status during late gestation and the early lactation period, postpartum uterine health, and the resumption of ovarian cyclicity.

\section{MATERIALS AND METHODS}

\section{Animal Model}

A genetic model of fertility was established in Teagasc Moorepark (Fermoy, Ireland) to elucidate the mechanisms responsible for poor fertility in lactating Holstein dairy cows (Cummins et al., 2012a,b,c). Briefly, heifers with $>75 \%$ Holstein genetics with extreme positive (i.e., poor fertility; Fert-) or negative (i.e., high fertility; Fert+) EBV for calving interval were selected from the national dairy cattle database. Within the Irish national herd, the selected heifers represented the top $25 \%$ in genetic merit for milk production. The Fertheifers represented the bottom $5 \%$ in genetic merit for calving interval, whereas the Fert+ heifers represented the top $20 \%$ in genetic merit for calving interval. In subsequent years, herd replacements were generated by selecting suitable sires to maintain the difference in genetic merit for calving interval. The list was restricted to sires with $>200 \mathrm{~kg}$ PTA for milk production, $>0 \%$ PTA milk fat and protein concentration, and $>75 \%$ Holstein genetics. From this group, sires with $>5$ d PTA for calving interval were selected for mating with Fertcows, and sires with $<-5$ d PTA for calving interval were selected for mating with Fert+ cows. Twenty-six cows were enrolled in the current study and the EBV of cows from both genotypes are summarized in Table 1. The Fert+ and Fert- cows were represented by 6 and 9 sires, respectively. The maximum and minimum number of daughters from an individual sire for Fert+ and Fert-cows was 4 and 1 and 2 and 1, respectively.

\section{Feed and Management System}

The experimental procedures involving animals on this study were licensed by the Department of Health, Ireland, in accordance with the Cruelty to Animals Act (Ireland 1876) and the European Community Directive 86/609/EEC. The study was undertaken at Teagasc Moorepark from January 2012 to December 2012. Cows were housed in a freestall barn during the dry period until $35 \mathrm{~d}$ postpartum. During the days approaching parturition, cows were moved to a strawbedded calving shed. Dry matter intake was recorded daily using the Griffith Elder feeding system (Griffith Elder Ltd., Bury St. Edmunds, Suffolk, UK). A prepartum diet of grass silage, concentrate ration, straw, and dry cow mineral mix was fed ad libitum. Postpartum cows were fed a TMR ad libitum plus $6 \mathrm{~kg}$ of dairy concentrate per day at the a.m. and p.m. milkings. Feed refusals were removed every second day. Diet ingredients were sampled weekly and composited monthly for analysis. The ingredient and nutrient compositions of the diets are outlined in Table 2. Cows were turned out to grass on March 26 and managed as one herd in a rotational grazing system. Cows grazed a predominantly perennial ryegrass (Lolium perenne L.) sward with fresh pasture allocated daily. The mean daily herbage allowance was $14.5 \pm 1.3 \mathrm{~kg}$ of DM/cow per day, which was supplemented with $3.2 \pm 0.2 \mathrm{~kg} /$ 
Table 1. The mean $\mathrm{EBV}^{1}$ (and SD) for both genotypes based on their sire, maternal grandsire (MGS), and maternal great-grandsire (MGGS) EBV

\begin{tabular}{|c|c|c|}
\hline \multirow[b]{2}{*}{ Item } & \multicolumn{2}{|c|}{ Genotype $^{2}$} \\
\hline & Fert+ & Fert- \\
\hline Animals (no.) & 15 & 11 \\
\hline Holstein & $94(4.7)$ & $95(5.5)$ \\
\hline Milk (kg) & $408(154.0)$ & $428(143.4)$ \\
\hline Fat $(\mathrm{kg})$ & $21.2(5.2)$ & $18.2(6.9)$ \\
\hline Fat $(\mathrm{g} / \mathrm{kg})$ & $0.09(0.08)$ & $0.02(0.1)$ \\
\hline Protein (kg) & $17.4(6.56)$ & $18.0(6.08)$ \\
\hline Protein $(\mathrm{g} / \mathrm{kg})$ & $0.05(0.06)$ & $0.05(0.07)$ \\
\hline Survival (\%) & $3.8(0.82)$ & $-3.4(1.12)$ \\
\hline Calving interval (d) & $-6.4(1.24)$ & $8.2(2.94)$ \\
\hline Sire calving interval (d) & $-9.3(2.4)$ & $12.3(2.4)$ \\
\hline Maternal grandsire calving interval (d) & $-7.9(3.34)$ & $10.9(4.5)$ \\
\hline
\end{tabular}

${ }^{1}$ The PTA were obtained from the autumn 2012 official dairy evaluations published by the Irish Cattle Breeding Federation and multiplied by 2 to convert to EBV. Individual cow EBV were determined using the following formula: $0.5 \times$ sireEBV $+0.25 \times$ MGS EBV $+0.125 \times$ MGGS EBV.

${ }^{2}$ Fert $+=$ good-fertility cows; Fert $-=$ poor-fertility cows. The parity structure of the Fert + cows was 3,4 , and 8 cows in second, third, and fourth lactations, respectively. The parity structure of the Fert- cows was 2, 3, and 6 cows in second, third, and fourth lactation, respectively.

cow per day of dairy concentrate fed at the a.m. and p.m. milkings.

\section{Animal Measurements}

Cows were milked twice daily at 0800 and $1600 \mathrm{~h}$. Milk yield was recorded at each milking using electronic milk meters (Dairymaster, Causeway, Co. Kerry, Ireland). Milk composition (fat, protein, and lactose) was determined weekly from successive p.m. and a.m. samples by mid-infrared reflectance spectroscopy (FT6000 Milkoscan instrument, Foss Electric, Hillerød, Denmark). Body weight and BCS were recorded weekly from wk 2 before calving to wk 15 of lactation and fortnightly thereafter. Body condition score was assessed using the 1 to 5 scale in 0.25 increments (Edmonson et al., 1989). Mean calving dates were February 11 (SD \pm $15.9 \mathrm{~d})$ and February $10(\mathrm{SD} \pm 10.6 \mathrm{~d})$ for Fert+ and Fert- cows, respectively. Energy balance was estimated as the difference between energy intake and the sum of energy for maintenance and milk production, using the French net energy system (Jarrige, 1989). This system expresses energy units as unité fourragère lait (UFL), which is the net energy content of $1 \mathrm{~kg}$ of air-dry standard barley for milk production. The energy requirements for maintenance and milk production were calculated using the equations developed by O'Mara (1997):

Energy requirement for maintenance $(\mathrm{UFL} / \mathrm{d})=$

$$
1.4+0.6 \mathrm{BW} / 100 \text {, and }
$$

Energy requirement for milk (UFL $/ \mathrm{kg}$ of milk) $=$

$$
0.054 \mathrm{FC}+0.031 \mathrm{PC}+0.028 \mathrm{LC}-0.015,
$$

where $\mathrm{FC}=$ fat concentration $(\%), \mathrm{PC}=$ protein concentration (\%), and LC = lactose concentration (\%).

Blood samples were collected weekly for 2 wk before expected date of calving, twice weekly during the first 4 wk after calving, and weekly thereafter until wk 8 postpartum following the a.m. milking. Blood samples were collected via coccygeal venipuncture into Vacutainers (Becton Dickinson, Plymouth, UK) containing lithium heparin and centrifuged at $2,000 \times g$ for $15 \mathrm{~min}$ at $4^{\circ} \mathrm{C}$; then, the plasma was decanted and stored at $-20^{\circ} \mathrm{C}$.

Milk samples were collected during the a.m. milking 3 times/wk (Monday, Wednesday, and Friday) using electronic milk meters (Dairymaster). Milk samples were preserved (Lactab MarkIII, Thomson and Capper Ltd., Cheshire, UK) and stored at $4^{\circ} \mathrm{C}$ until progesterone analysis.

Vaginal mucus was collected weekly after calving following the a.m. milking. The vulva and perineal area were sanitized with an antiseptic solution and dried with paper towels. A clean, lubricated, gloved hand was inserted through the vulva, mucus was collected from the vagina into a $50-\mathrm{mL}$ conical tube for inspection, and a character score was determined based on the criteria outlined by Williams et al. (2005): $0=$ clear and translucent mucus; $1=$ mucus containing flecks of white or off-white pus; $2=<50 \%$ white or off-white mucopurulent material; or $3=\geq 50 \%$ white or off-white mucopurulent material.

Uterine cytology samples were collected on d 21 (SD $\pm 1 \mathrm{~d})$ and $\mathrm{d} 42(\mathrm{SD} \pm 2 \mathrm{~d})$ postpartum. For each cow, uterine cytology samples were collected before vaginal mucus collection when both coincided. The vulva and perineal area were sanitized with antiseptic solution and dried with paper towels. An AI cannula $(53 \mathrm{~cm})$, 
Table 2. Ingredient and nutrient composition of the transition period diet

\begin{tabular}{|c|c|c|}
\hline Item & \multicolumn{2}{|c|}{ Value } \\
\hline \multicolumn{3}{|l|}{ Dry cow diet $(\mathrm{g} / \mathrm{kg}$ of $\mathrm{DM})$} \\
\hline Grass silage & \multicolumn{2}{|c|}{760} \\
\hline Straw & \multicolumn{2}{|c|}{140} \\
\hline Concentrate & \multicolumn{2}{|c|}{100} \\
\hline \multicolumn{3}{|c|}{ Dry cow concentrate ingredients ( $\mathrm{g} / \mathrm{kg}$ as fed) } \\
\hline Barley & \multicolumn{2}{|c|}{250} \\
\hline Soy hulls & \multicolumn{2}{|c|}{150} \\
\hline Rapeseed & \multicolumn{2}{|c|}{150} \\
\hline Palm kernel meal & \multicolumn{2}{|c|}{100} \\
\hline Milk solids & \multicolumn{2}{|c|}{80} \\
\hline Sunflower meal & \multicolumn{2}{|c|}{75} \\
\hline Citrus pulp & \multicolumn{2}{|c|}{60} \\
\hline Dried distillers grains & \multicolumn{2}{|c|}{60} \\
\hline Maize gluten & \multicolumn{2}{|c|}{44} \\
\hline Minerals $^{1}$ & \multicolumn{2}{|c|}{25} \\
\hline Palm oil & \multicolumn{2}{|c|}{6} \\
\hline \multicolumn{3}{|l|}{ Lactating cow diet ( $\mathrm{g} / \mathrm{kg}$ of $\mathrm{DM})$} \\
\hline Grass silage & \multicolumn{2}{|c|}{340} \\
\hline Maize silage & \multicolumn{2}{|c|}{310} \\
\hline Soybean meal & \multicolumn{2}{|c|}{110} \\
\hline Molasses & \multicolumn{2}{|c|}{20} \\
\hline Parlor concentrate & \multicolumn{2}{|c|}{230} \\
\hline \multicolumn{3}{|c|}{ Lactating cow concentrate ingredients ( $\mathrm{g} / \mathrm{kg}$ as fed) } \\
\hline Barley & \multicolumn{2}{|c|}{320} \\
\hline Soy hulls & \multicolumn{2}{|c|}{205} \\
\hline Rapeseed & \multicolumn{2}{|c|}{140} \\
\hline Field beans & \multicolumn{2}{|c|}{100} \\
\hline Dried distillers grains & \multicolumn{2}{|c|}{100} \\
\hline Molasses & & \\
\hline Citrus pulp & & \\
\hline Minerals $^{2}$ & & \\
\hline Nutrient composition of concentrate & Dry cow & Lactating cow \\
\hline $\mathrm{DM}(\mathrm{g} / \mathrm{kg})$ & 854 & 872 \\
\hline Net energy $(\mathrm{UFL} / \mathrm{kg} \text { of } \mathrm{DM})^{3}$ & 0.92 & 1.12 \\
\hline Ash $(\mathrm{g} / \mathrm{kg}$ of $\mathrm{DM})$ & 78.4 & 37 \\
\hline $\mathrm{CP}(\mathrm{g} / \mathrm{kg}$ of $\mathrm{DM})$ & 159 & 142 \\
\hline $\operatorname{NDF}(\mathrm{g} / \mathrm{kg}$ of $\mathrm{DM})$ & 506 & 251 \\
\hline
\end{tabular}

${ }^{1}$ Vitamin and mineral mix: $256 \mathrm{~g} / \mathrm{kg}$ of $\mathrm{Na}, 150 \mathrm{~g} / \mathrm{kg}$ of $\mathrm{Mg}, 14,000 \mathrm{mg} / \mathrm{kg}$ of cupric sulfate pentahydrate, 5,556 $\mathrm{mg} / \mathrm{kg}$ of zinc oxide, $198 \mathrm{mg} / \mathrm{kg}$ of cobaltous carbonate monohydrate, $110 \mathrm{mg} / \mathrm{kg}$ of sodium selenite, $1,613 \mathrm{mg} /$ $\mathrm{kg}$ of manganous oxide, $806 \mathrm{mg} / \mathrm{kg}$ of calcium iodate anhydrous, $275,000 \mathrm{IU} / \mathrm{kg}$ of vitamin A, 75,000 IU/ $\mathrm{kg}$ of vitamin D, $500 \mathrm{mg} / \mathrm{kg}$ of vitamin $\mathrm{E}$, and $200 \mu \mathrm{g} / \mathrm{kg}$ of vitamin $\mathrm{B}_{12}$.

${ }^{2}$ Vitamin and mineral mix: $229 \mathrm{~g} / \mathrm{kg}$ of $\mathrm{Ca}, 100 \mathrm{~g} / \mathrm{kg}$ of Na, $70 \mathrm{~g} / \mathrm{kg}$ of P, $5 \mathrm{~g} / \mathrm{kg}$ of Mg, 4,500 mg/kg of Zn, $3,000 \mathrm{mg} / \mathrm{kg}$ of $\mathrm{Cu}, 1,500 \mathrm{mg} / \mathrm{kg}$ of $\mathrm{Mn}, 500 \mathrm{mg} / \mathrm{kg}$ of I, $400 \mathrm{mg} / \mathrm{kg}$ of Bioplex Cu (Alltech Inc., Nicholasville, $\mathrm{KY}), 400 \mathrm{mg} / \mathrm{kg}$ of Bioplex Zn (Alltech Inc.), $99 \mathrm{mg} / \mathrm{kg}$ of Co, $37 \mathrm{mg} / \mathrm{kg}$ of Se, 375,000 IU $/ \mathrm{kg}$ of vitamin A, $100,000 \mathrm{IU} / \mathrm{kg}$ of vitamin $\mathrm{D}_{3}, 1,250 \mathrm{mg} / \mathrm{kg}$ of vitamin $\mathrm{E}$, and $200 \mathrm{mg} / \mathrm{kg}$ of vitamin $\mathrm{B}_{12}$.

${ }^{3} \mathrm{UFL}=$ unité fourragère lait, which is the net energy content of $1 \mathrm{~kg}$ of air-dry standard barley for milk production.

enclosed by an embryo transfer (ET) plastic sheath (IMV Technologies, L'Aigle, France) was placed in a plastic sleeve. The apparatus was guided through the cervix to the common body, and the plastic sleeve was pierced. The AI gun was removed, leaving the ET plastic sheath in situ. A sterile cytology brush attached to copper wire $(49 \mathrm{~cm})$ was guided through the ET plastic sheath to the uterine body. An endometrial cytology sample was collected by one gentle rotation of the cytobrush against the uterine wall. The cytobrush was retracted into the ET plastic sheath and both were withdrawn from the uterus. The AI cannula was placed in disinfectant (Meddis, Medichem International Ltd., Sevenoaks, UK) between uses. The cytobrush was smeared against glass microscope slides, in duplicate, which were allowed to air-dry and stained in the laboratory $24 \mathrm{~h}$ later. Smears were fixed to the slides with methanol. Slides were stained with separate eosin and thiazine reagents (Wescor Inc., South Logan, UT) by a slide stainer (Wescor Aerospray Automatic Slide Stainer, Wescor Inc.). The reagents were rinsed from the slide with an eosin rinse. Each slide was evaluated at $100 \times$ magnification by a single cytologist blind to the cow genotype. One hundred nucleated cells were 
counted, from which the percentage that were PMNL was calculated.

\section{Hormone and Metabolite Analysis}

Plasma samples collected at wk $-2,-1,0,0.5,1$, $1.5,2,2.5,3,3.5,4,5,6,7$, and 8 relative to parturition (wk 0) were analyzed for concentrations of NEFA, BHBA, and glucose by enzymatic colorimetry using an ABX Pentra 400 autoanalyser (ABX Mira, Montpellier, France; NEFA kit supplied by Wako Chemicals GmBH, Neuss, Germany; BHBA kit supplied by Randox Laboratories Ltd., Crumlin, UK; glucose kit supplied by Horiba ABX, Montpellier, France). Plasma samples collected at wk $-2,0,2,4,6$, and 8 relative to parturition (0) were analyzed for concentrations of insulin and IGF-I. Concentrations of insulin were determined by solid-phase ${ }^{125} \mathrm{I}$ RIA (Coat-A-Count Insulin, Diagnostic Products Corp., Los Angeles, CA). Inter- and intraassay coefficients of variation were 7.8 and $13.5 \%$, respectively. Concentrations of IGF-I were determined by validated double antibody. Both genotypes were equally represented in each assay and all samples for a cow were completed in a RIA, following ethanol:acetone:acetic acid extraction. Inter- and intraassay coefficients of variation were 2.7 and $12.1 \%$, respectively.

Milk progesterone concentrations were measured using a competitive ELISA test (Ridgeway Science, Gloucester, UK). The inter- and intraassay coefficients of variation were 7.8 and $9.7 \%$, respectively, and the sensitivity of the assay was $0.5 \mathrm{ng} / \mathrm{mL}$.

\section{Data Handling}

All data handling was performed using SAS (SAS Institute, 2006). Twenty-six cows were enrolled in this study. Records of 1 Fert- cow were removed from the statistical analysis due to ill health. Data collected beyond lactation wk 35 were excluded from the analysis because nonpregnant cows were culled before completing a full lactation. Daily measurements of milk, fat, protein, and lactose yields were collapsed into average weekly yields. The milk fat:protein ratio was calculated by dividing the milk fat percentage by the milk protein percentage. Data were checked for normality. Suitable Box-Cox transformations were identified to normalize the distribution of lactose, MUN, BHBA, insulin, IGF-I, NEFA, and PMNL count data. The distribution of SCC data was normalized by natural logarithm transformation and reported as SCS. Dry matter intake and energy balance data were available for 22 cows (12 Fert+ and 10 Fert) during the transition period. These data were analyzed as 2 periods: prepartum (data for the final $3 \mathrm{wk}$ before calving date) and postpartum (data for the first 5 wk after calving date). Linear interpolation was performed to calculate BW and BCS values for every week of the study. Blood metabolite and metabolic hormone data were analyzed from $2 \mathrm{wk}$ prepartum to 8 wk postpartum. In addition, glucose concentrations were also analyzed from 2 wk prepartum to 3 wk postpartum. Cows were classified as having subclinical ketosis if BHBA concentrations were $\geq 1.2$ and $\leq 2.9 \mathrm{mmol} / \mathrm{L}$ at least once during the first 3 wk of lactation and were classified as having clinical ketosis if BHBA concentrations were $>2.9 \mathrm{mmol} / \mathrm{L}$ at least once during the first $3 \mathrm{wk}$ of lactation (Oetzel, 2004). The timing of the BCS and BW nadir was identified as the earliest week during the first $15 \mathrm{wk}$ postpartum that the lowest value was recorded. Cows were classified as having endometritis at wk 3 if PMNL counts were greater than $18 \%$, and at wk 6 if PMNL counts were greater than 10\% (Sheldon et al., 2006).

\section{Statistical Analysis}

All statistical analysis was performed using SAS software (SAS Institute, 2006). Mixed model procedures were used to determine the effect of genotype on variables with repeated measures such as milk production, BW, BCS, DMI, energy balance, blood metabolite, and metabolic hormone concentrations. A first-order autoregressive covariance structure was applied, and cow nested within genotype was included as a random effect. Genotype, lactation week, and their interaction were included as fixed effects. Parity, calving date, and their interactions with genotype were included initially but removed if not significant $(P>0.1)$. The Tukey adjustment was included to correct for multiple comparison tests. Contrasts were written to compare glucose, insulin, and IGF-I concentrations at individual time points between genotypes. The effect of genotype on specific BCS variables (i.e., BCS at calving, postpartum BCS nadir, week of BCS nadir, BCS change from calving to nadir) and weekly vaginal mucus scores were analyzed by one-way nonparametric test. Logistic regression was carried out using the GENMOD procedure to determine the effect of genetic merit for fertility traits on binary variables such as the proportion of animals classified as having endometritis, the proportion of animals to have resumed postpartum cyclicity, and the proportion of animals classified with subclinical or clinical ketosis. Parity and calving date were included in the initial model but removed if not significant. Data were assumed to be binomially distributed and a logit link function was used in the model statement. The model tested the probability of a positive response and predicted probabilities were calculated from model solu- 
Table 3. The effect of genetic merit for fertility traits on daily milk production variables during the first 35 wk of lactation

\begin{tabular}{|c|c|c|c|c|c|}
\hline \multirow[b]{2}{*}{ Variable } & \multicolumn{2}{|c|}{ Genotype $^{1}$} & \multirow[b]{2}{*}{$\mathrm{SEM}^{2}$} & \multicolumn{2}{|c|}{$P$-value } \\
\hline & Fert+ & Fert- & & Genotype & $\begin{array}{c}\text { Genotype } \\
\times \text { week }\end{array}$ \\
\hline Animal records (no.) & 15 & 10 & & & \\
\hline Milk yield $(\mathrm{kg} / \mathrm{d})$ & 24.2 & 22.3 & 0.88 & 0.08 & 0.5 \\
\hline Protein $(\mathrm{g} / \mathrm{kg}$ of milk $)$ & 34.6 & 33.4 & 0.05 & 0.1 & 0.98 \\
\hline Fat (g/kg of milk) & 43.8 & 43.8 & 0.11 & 0.98 & 0.66 \\
\hline Lactose $^{3}(\mathrm{~g} / \mathrm{kg}$ of milk $)$ & $46.3(45.6-46.9)$ & $45.5(44.6-46.3)$ & - & 0.14 & 0.85 \\
\hline $\mathrm{MUN}^{3}(\mathrm{~g} / \mathrm{kg}$ of milk) & $31.9(29.7-34.3)$ & $31.1(29.2-33.1)$ & - & 0.6 & 0.84 \\
\hline Milk solids $^{4}(\mathrm{~kg} / \mathrm{d})$ & 1.89 & 1.74 & 0.05 & 0.05 & 0.99 \\
\hline Fat:protein ratio & 1.27 & 1.30 & 0.03 & 0.42 & 0.53 \\
\hline SCS units ${ }^{3}$ & $3.94(3.50-4.39)$ & $4.22(3.67-4.77)$ & - & 0.38 & 0.06 \\
\hline
\end{tabular}

${ }^{1}$ Fert $+=$ good-fertility cows; Fert $-=$ poor-fertility cows.

${ }^{2}$ Pooled standard error.

${ }^{3}$ Data presented as LSM with $95 \%$ CI in parentheses.

${ }^{4}$ Sum of fat and protein yield.

tions using the formula $P P=\left(1+\mathrm{e}^{-(\alpha+\beta \mathbf{x})}\right)$, where $\alpha$ is the predicted intercept of the model, $\beta$ is the predicted regression coefficient(s), and $\mathbf{x}$ is the design matrix for the fixed effects. Odds ratios and confidence intervals were calculated as the exponent of model solutions. The Fert+ cows were set as the reference group. Odds ratios are reported for Fert- cows relative to Fert+ cows. The interval from calving to achieving a vaginal mucus score of zero was determined by survival analysis using the LIFETEST procedure. In the analysis of postpartum interval to achieve a vaginal mucus score of zero, 2 cows were censored (1 Fert+ and 1 Fert-) at wk 1 postpartum because they received intrauterine antibiotic.

\section{RESULTS}

\section{Milk Production}

The effect of genetic merit for fertility traits is summarized in Table 3. During the first $35 \mathrm{wk}$, Fert+ cows tended to have greater mean daily milk yield $(+1.9$ $\mathrm{kg} / \mathrm{d} ; P=0.08)$ and had greater $(P=0.05)$ mean daily milk solids production $(1.89 \pm 0.05 \mathrm{~kg} / \mathrm{d})$ than Fertcows $(1.74 \pm 0.06 \mathrm{~kg} / \mathrm{d}$; Figure 1$)$. Mean milk protein $(+1.2 \mathrm{~g} / \mathrm{kg}$ of milk) and lactose $(+0.8 \mathrm{~g} / \mathrm{kg}$ of milk $)$ concentrations tended to be greater (both $P=0.1$ ) in Fert+ cows compared with Fert- cows. Genotype had no effect on mean milk fat $(P=0.98)$ or MUN ( $P$ $=0.6)$ concentrations, milk fat:protein ratio, or SCS (both $P=0.4$ ).

\section{Energy Balance, DMI, BCS, and BW}

The effect of genetic merit for fertility traits on DMI and energy balance profiles from wk 2 prepartum to wk 5 postpartum are shown in Figure 2. Genotype had no effect on the mean prepartum DMI (14.8 vs. 14.3 $\mathrm{kg}$ of DM/d for Fert+ and Fert- cows, respectively; $P$ $=0.63$ ) but Fert + cows had greater mean postpartum DMI than Fert- cows (19.7 vs. $16.8 \mathrm{~kg}$ of DM/d; $P=$ $0.02)$. Neither prepartum (6.1 vs. $5.5 \mathrm{UFL} / \mathrm{d}$ for Fert+ and Fert- cows, respectively; $P=0.45)$ nor postpartum $(-0.3$ vs. $-1.2 \mathrm{UFL} / \mathrm{d}$ for Fert+ and Fert- cows, respectively; $P=0.37$ ) energy balance was affected by genotype. However, energy balance at wk 1 was greater in Fert+ than in Fert- cows (2.3 vs. $-1.2 \mathrm{UFL} / \mathrm{d}, P$ $=0.02)$. Mean BCS and BW profiles from $\mathrm{wk}-2$ to 35 relative to parturition are shown in Figure 3. Mean BCS (2.98 vs. 2.75 units, $P<0.0001)$ and BW (578.5 vs. $545.8 \mathrm{~kg}, P=0.05)$ were greater in Fert+ cows than in Fert- during the study period. Mean BCS at calving and the timing of BCS nadir were similar for both genotypes (Table 4) but the loss of body condition tended to be greater in Fert- cows than in Fert+ cows (additional 0.13 BCS loss; $P=0.1$ ). At nadir, Fert+ cows had greater mean BCS than Fert - cows $(P=0.009)$.

\section{Blood Metabolites and Metabolic Hormones}

The effect of genetic merit for fertility traits on circulating metabolites from $2 \mathrm{wk}$ prepartum to $8 \mathrm{wk}$ postpartum is illustrated in Figure 4. Mean circulating glucose $(P=0.19)$, NEFA $(P=0.64)$, and BHBA $(P=$ $0.92)$ concentrations during the period were similar in Fert+ and Fert- cows; however, mean circulating glucose concentrations were greater $(P=0.04)$ in Fert+ $(3.40 \mathrm{mmol} / \mathrm{L})$ cows than in Fert- $(3.01 \mathrm{mmol} / \mathrm{L})$ cows from wk -2 to 3 relative to parturition. Four Fertand 4 Fert + cows were classified as having subclinical ketosis, but we detected no effect of genotype $(P=$ 0.49). Of these, 1 Fert+ and 1 Fert- cow were classified 

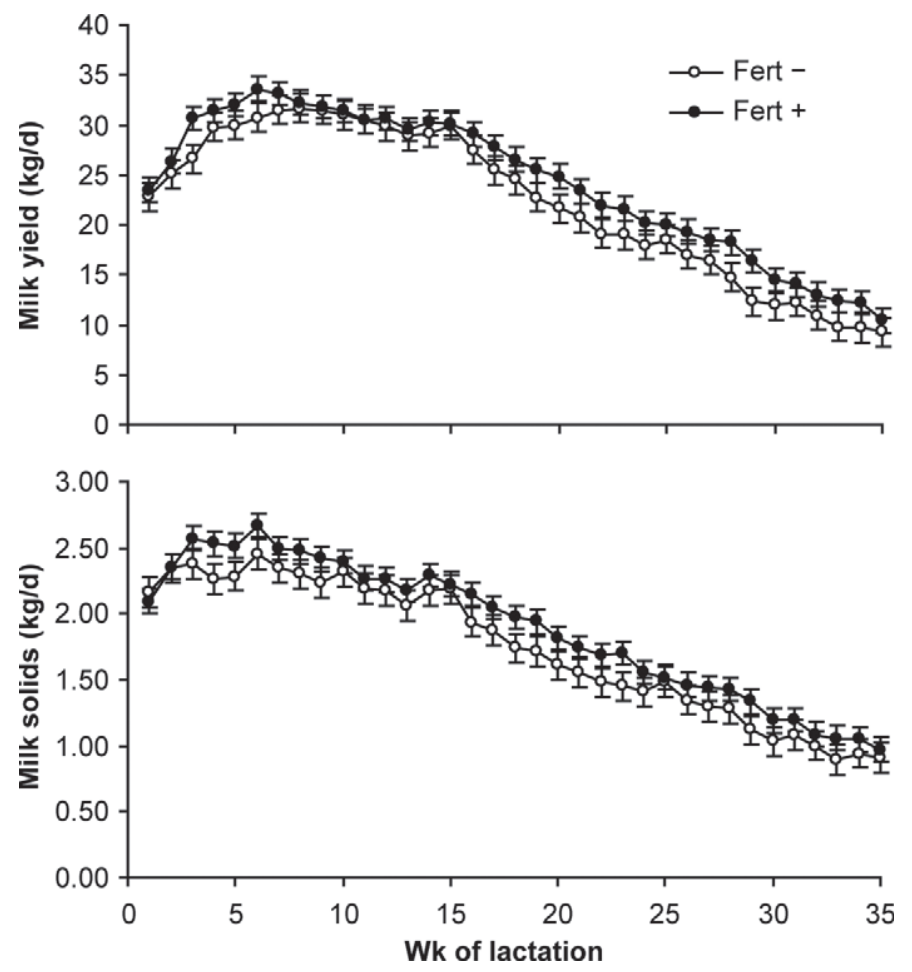

Figure 1. Mean daily milk yield and milk solids yield profiles of good- and poor-fertility (Fert+ and Fert-) cows during 35 wk of lactation. All values are LSM. Mean daily milk yield tended to be greater in Fert + cows than Fert - cows $(P=0.08 ; \mathrm{SEM}=0.88)$. Mean daily milk solids yield $(P=0.05$; $\mathrm{SEM}=0.06)$ was greater in Fert+ cows compared with Fert- cows.

as having clinical ketosis, but we detected no effect of genotype $(P=0.75)$. A genotype by week interaction existed for NEFA $(P=0.02$; Figure 4$)$. Mean circulating IGF-I and insulin concentrations for both genotypes are illustrated in Figure 5: Fert+ cows had greater mean IGF-I concentrations than Fert- cows (102.62 vs. $56.85 \mathrm{ng} / \mathrm{mL}, P=0.001)$. We detected a genotype by week interaction for mean IGF-I concentrations $(P=$ 0.0009); the difference between genotypes decreased as time increased. The Fert + cows tended to have greater mean circulating insulin concentrations than Fertcows (3.25 vs. $2.62 \mu \mathrm{IU} / \mathrm{mL}, P=0.08)$. We observed a tendency for a genotype by week interaction for mean circulating concentrations $(P=0.04$; Figure 5).

\section{Postpartum Uterine Health}

The effect of genetic merit for fertility traits on postpartum vaginal mucus score is summarized in Table 5. The Fert- cows had a greater vaginal mucus score than the Fert+ cows in wk 2 and 3 and tended to be greater in wk 4 to 6 . Survival analysis indicated that the postpartum interval required to achieve a vaginal mucus score of zero was not affected by genotype $(P=$
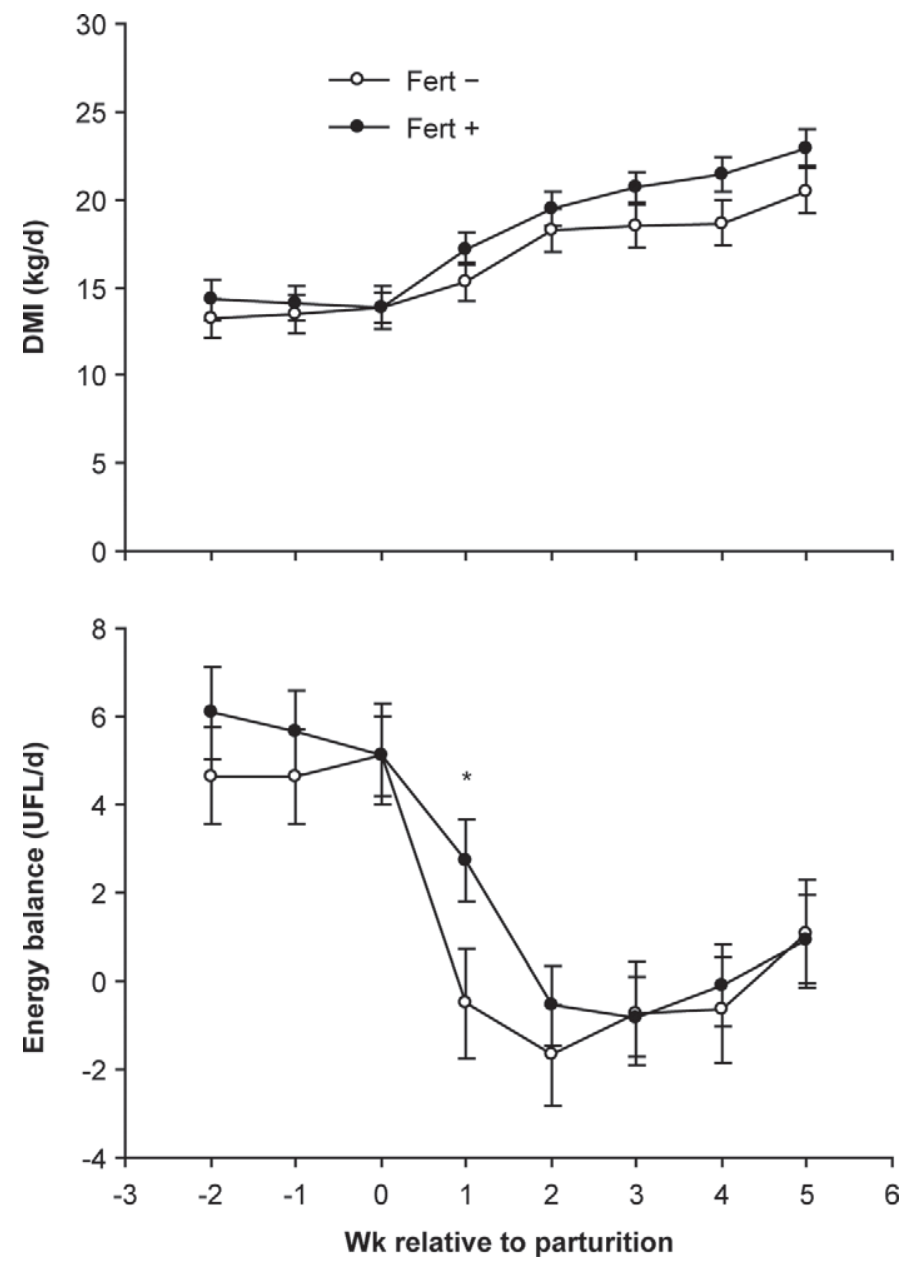

Figure 2. Mean DMI and calculated energy balance of good- and poor-fertility (Fert+ and Fert-) cows from wk -2 to 5 relative to parturition. Prepartum DMI was similar for both genotypes $(P=0.63$; $\mathrm{SEM}=0.75)$, but postpartum DMI was greater in Fert + cows compared with Fert - cows $(P=0.02 ; \mathrm{SEM}=0.79)$. Mean prepartum $(P$ $=0.45 ; \mathrm{SEM}=0.54)$ and postpartum $(P=0.37 ; \mathrm{SEM}=0.71)$ energy balance were similar for both genotypes. Energy balance at wk 1 was greater in Fert + cows than in Fert- cows $(P=0.02)$. UFL $=$ unité fourragère lait. ${ }^{*} P \leq 0.05$.

0.26). On wk 3 postpartum, we observed no effect of genotype on the mean PMNL counts (Table 6) but did find a tendency for Fert- cows to have increased odds of being classified as having endometritis $(P=0.09)$. At wk 6 postpartum, Fert- cows had greater mean PMNL counts $(P=0.04)$, and they had increased odds of being classified as having endometritis compared with Fert + cows $(P=0.04)$.

\section{Postpartum Resumption of Cyclicity}

Two of 10 Fert- cows and 12 of 14 Fert+ cows had resumed cyclicity by wk 6 after calving. The Fert- cows had reduced odds of having resumed cyclicity by wk 6 
Table 4. The effect of genetic merit for fertility traits on mean BCS and BW variables

\begin{tabular}{|c|c|c|c|c|c|}
\hline \multirow[b]{2}{*}{ Variable } & \multicolumn{2}{|c|}{ Genotype $^{1}$} & \multirow[b]{2}{*}{$\mathrm{SEM}^{2}$} & \multicolumn{2}{|c|}{$P$-value } \\
\hline & Fert+ & Fert- & & Genotype & $\begin{array}{c}\text { Genotype } \\
\times \text { week }\end{array}$ \\
\hline Animal records (no.) & 10 & 15 & - & & - \\
\hline Mean BW $(\mathrm{kg})$ & 579 & 546 & 11 & 0.05 & 1.00 \\
\hline Mean BCS & 2.98 & 2.75 & 0.02 & $<0.001$ & 0.27 \\
\hline BCS at calving & 3.12 & 2.98 & - & 0.14 & - \\
\hline $\mathrm{BCS}$ at nadir & 2.75 & 2.45 & - & 0.009 & - \\
\hline Week of BCS nadir & 6.90 & 6.89 & - & 0.98 & - \\
\hline BCS change from calving to nadir & -0.35 & -0.48 & 0.06 & 0.10 & - \\
\hline
\end{tabular}

${ }^{1}$ Fert $+=$ good-fertility cows; Fert $-=$ poor-fertility cows.

${ }^{2}$ Pooled standard error.

after calving compared with Fert+ cows (odds ratio $=$ $0.04 ; 95 \%$ CI $=0.01-0.36, P=0.009)$.

\section{DISCUSSION}

In dairy cattle, genetic selection in the past decades focused solely on increasing milk production without regard to health and fertility traits, resulting in large increases in milk production and a decline in reproductive performance (Lucy, 2001; Pollott and Coffey, 2008). The 2 genotypes of cows enrolled on this study had similar genetic merit for milk production but were divergent in genetic merit for fertility traits. Cows from both genotypes were exposed to the same management
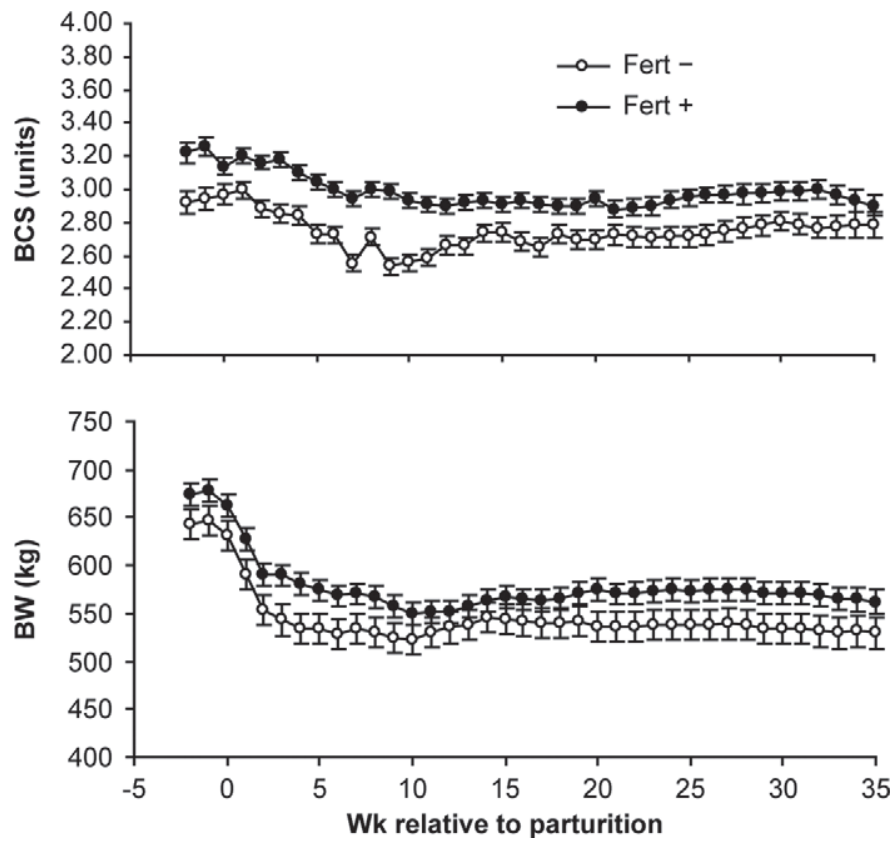

Figure 3. Mean BCS and BW in good- and poor-fertility (Fert+ and Fert-) cows from wk -2 to 35 relative to parturition. Fert+ cows maintained greater mean BCS $(P<0.001$; SEM 0.02) and BW $(P=$ $0.05 ; \mathrm{SEM}=11.09)$ than Fert- cows from wk -2 to 35. and nutrition, allowing the effect of genetic merit for fertility traits on phenotypic fertility measurements to be assessed. The results of this study indicate that it is possible to select animals with good genetic merit for fertility traits without compromising milk production. The Fert+ cows had greater milk yield and milk solids production compared with Fert- cows. This is in agreement with the results of Cummins et al. (2012a) and validates the robustness of the animal model. Some disagreement exists between studies that have examined the relationship between milk production and reproductive performance. Conclusions have ranged from a negative association (Nebel and McGilliard, 1993), to no association (Patton et al., 2007), to a positive association (Buckley et al., 2003). It has also been suggested that factors such as herd management and animal health should be taken into account when investigating the interactions between production and fertility (Leblanc, 2010; Bello et al., 2012). In the current study, these concerns were avoided by managing both groups of cows as a single herd with similar nutrition and similar health protocols.

\section{DMI and Energy Balance}

Dry matter intake and energy balance have previously been shown to be positively associated with fertility (Butler and Smith, 1989; Patton et al., 2007). In the current study, however, mean energy balance during the first 5 wk of lactation was similar in Fert+ and Fert- cows. This is consistent with Patton et al. (2008), who reported no difference in early lactation energy balance between strains of Holstein Friesian from New Zealand (high fertility) and North America (low fertility). However, energy balance during wk 1 of lactation was greater in Fert+ cows than in Fert- cows. The greater DMI during the first 5 wk of lactation in Fert+ cows compared with Fert- cows is an important finding from this study. Dry matter intake has been reported to account for the majority of the variation 

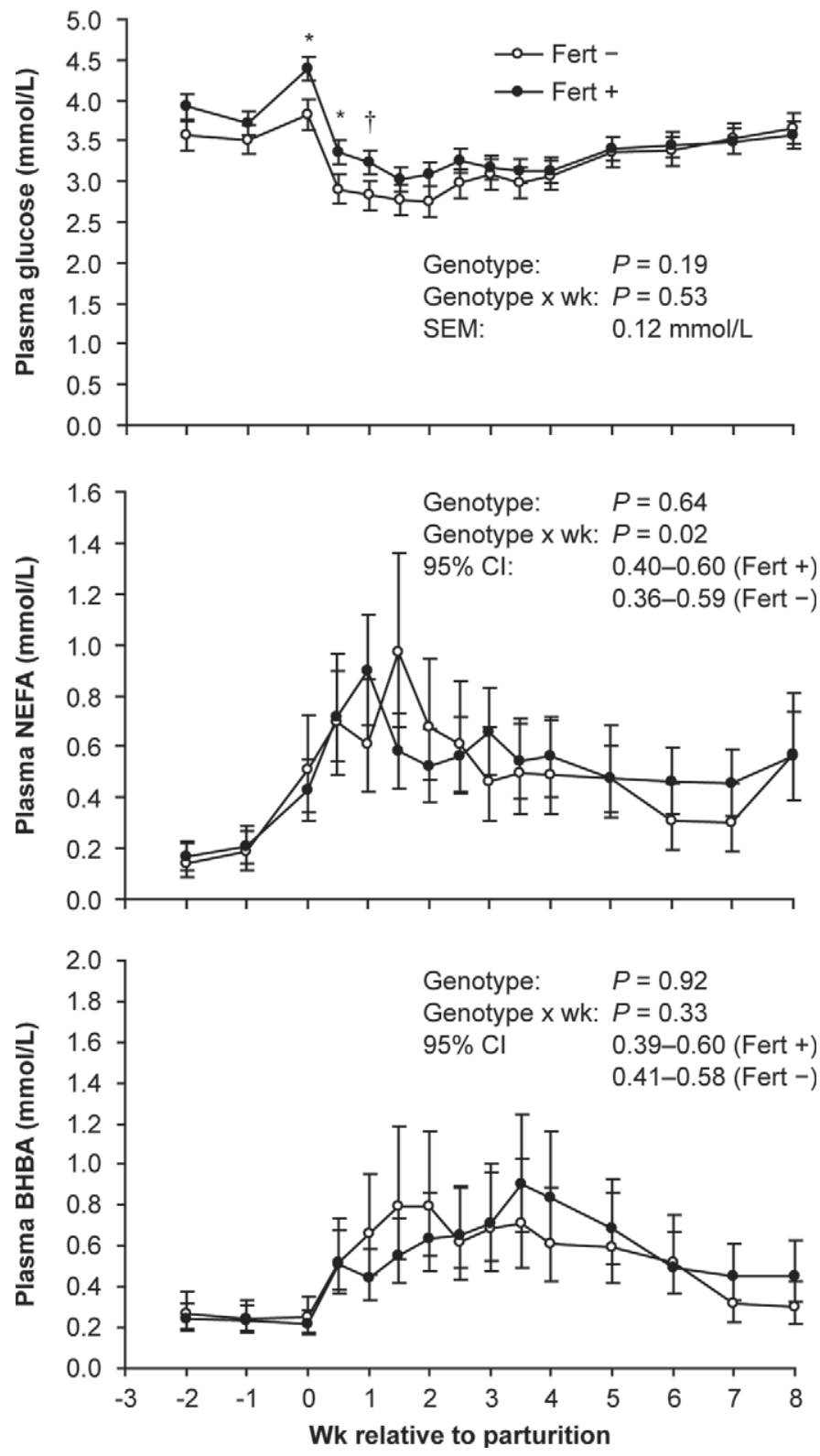

Figure 4. Mean circulating glucose, NEFA, and BHBA concentrations in good- and poor-fertility (Fert+ and Fert-) cows from wk -2 to 8 relative to parturition. Mean plasma glucose, NEFA, and BHBA were similar in both genotypes. Values for NEFA and BHBA are backtransformed LSM with $95 \%$ CI. ${ }^{*} P \leq 0.05 ; \dagger P \leq 0.1$.

in energy balance during the early postpartum period (Villa-Godoy et al., 1988; Patton et al., 2007) and is the main factor limiting milk production (Roche et al., 2008). Feed allowance and type of feed, management, day length, weather, genetics, milk production, stage of production cycle, and health status are factors that affect an animal's voluntary feed intake (Roche et al., 2008; Sepúlveda-Varas et al., 2013). Lower DMI in the first week postpartum is associated with increased incidence of subclinical ketosis (Goldhawk et al., 2009) and metritis (Huzzey et al., 2007). In the current study, mean circulating concentrations of NEFA and BHBA and the incidence of subclinical and clinical ketosis were not affected by genotype. We did, however, observe clear differences in uterine health between the 2 genotypes: Fert- cows had greater mean vaginal mucus scores from wk 2 to 8 and a greater proportion were classified as having endometritis at wk 6 compared with Fert+ cows. This suggests that lower postpartum DMI is a factor predisposing Fert- cows to impaired uterine health. These data suggest an association between DMI and uterine health in Fert+ and Fert- cows that may support the results of Huzzey et al. (2007).
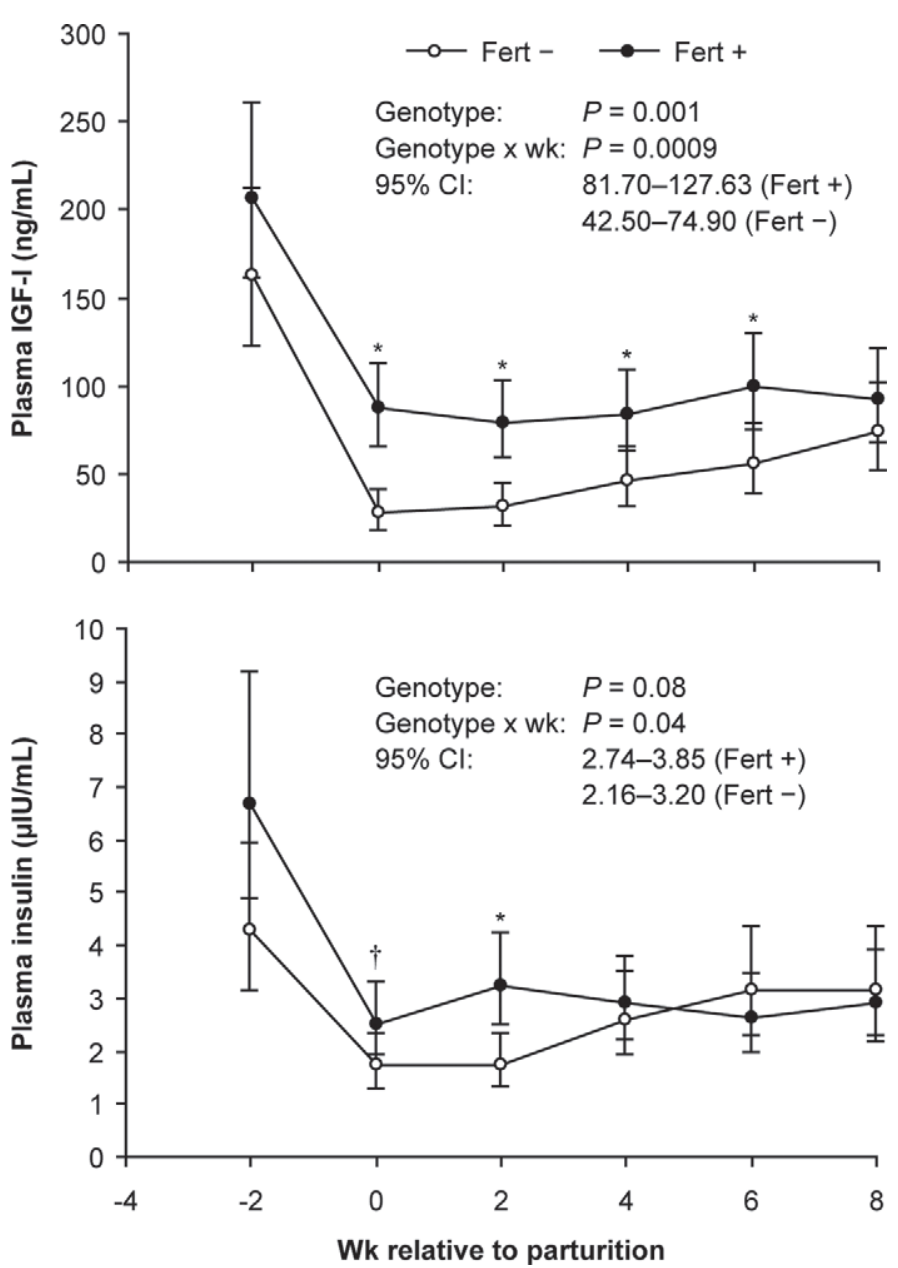

Figure 5. Mean circulating IGF-I and insulin in good- and poorfertility (Fert+ and Fert-) cows from wk -2 to 8 relative to parturition. Plasma IGF-I was greater in Fert+ cows than in Fert- cows during the sampling period $(P=0.001)$ and the difference between genotypes decreased as time increased $(P<0.0009)$. Plasma insulin tended to be greater in Fert+ cows than in Fert- cows during the sampling period $(P=0.08)$ and we detected a genotype by time interaction $(P=0.04)$. All values are back-transformed LSM with $95 \%$ CI. ${ }^{*} P \leq 0.05 ; \dagger P \leq 0.1$. 
Table 5. The effect of genetic merit for fertility traits on mean vaginal mucus score in Fert+ and Fert- cows until wk 8 of lactation

\begin{tabular}{lccc}
\hline & \multicolumn{2}{c}{ Genotype $^{1}$} & \\
\cline { 2 - 3 } Week & Fert+ (no.) & Fert- (no.) & P-value \\
\hline 1 & $1.9(15)$ & $2.3(10)$ & 0.31 \\
2 & $0.9(15)$ & $2.5(10)$ & 0.03 \\
3 & $1.1(14)$ & $2.2(10)$ & 0.04 \\
4 & $0.4(14)$ & $1.1(10)$ & 0.09 \\
5 & $0.4(14)$ & $1.2(10)$ & 0.08 \\
6 & $0.0(11)$ & $1.2(9)$ & 0.06 \\
7 & $0.0(8)$ & $0.2(6)$ & 0.26 \\
8 & $0.1(7)$ & $0.0(1)$ & 0.74 \\
\hline${ }^{1}$ Fert+ = good-fertility cows; Fert- $=$ poor-fertility cows.
\end{tabular}

\section{Energy Metabolites and Metabolic Hormones}

Greater circulating glucose, insulin, and IGF-I concentrations during the transition period indicate that Fert+ cows were in a more favorable metabolic status compared with Fert- cows. These results imply an earlier recoupling of the somatotropic axis in Fert+ cows, supporting the findings of Cummins et al. (2012a,c) that genetic merit for fertility traits affects the somatotropic axis. This might be due to greater circulating insulin, which has been reported to upregulate hepatic expression of growth hormone receptor $1 \mathrm{~A}$ and IGF-I transcripts (Butler et al., 2003). Taylor et al. (2004) and Patton et al. (2007) have reported a positive association between circulating IGF-I and fertility in dairy cows, which is mediated through its positive effect on luteinizing hormone secretion, follicle development, histotroph secretion, and embryo development (Wathes, 2012). A positive association between circulating glucose during the early postpartum period and likelihood of conception at first service has recently been reported (Garverick et al., 2013). Circulating glucose concentrations during the immediate postpartum period may be a key indicator of a cow's adaptive ability to meet the glucose demands of rising milk production while minimizing BCS loss, with longer-term consequences for subsequent reproductive outcomes (i.e., uterine involution, immune function and uterine health, resumption of cyclicity, likelihood of conception). It is clear from the current study that genetic selection for fertility traits results in more favorable glucose status in early lactation, which may represent a key inherent difference between cows with good or poor genetic merit for fertility traits.

\section{BCS}

With the onset of lactation, the dairy cow experiences a dramatic shift in metabolism due to the genetically controlled drive to support mammary milk synthesis. Consequently, a period of negative energy balance and adipose tissue mobilization occurs, reflected by increased circulating NEFA concentrations (Drackley, 1999). Genetic selection for increased milk production potential has amplified the severity of adipose tissue mobilization (McCarthy et al., 2007; Lucy et al., 2009). Body condition score is an assessment of adipose tissue reserves and can be used to detect temporal changes in energy balance status. Increased severity of adipose tissue mobilization may be due to the widening gap between the energy required for greater milk production and the cow's voluntary DMI. Veerkamp et al. (2003) reported a genetic correlation of only 0.44 to 0.65 between milk yield and DMI. In both pasture-based and TMR systems, however, attempts to minimize adipose tissue mobilization during the early postpartum period through altered nutritional and management strategies have been largely unsuccessful (Horan et al., 2005a; Roche et al., 2006; Maltz et al., 2013), indicating that there is strong genetic control of the lactation profile of adipose tissue mobilization. Berry et al. (2008) reported that heritability estimates for BCS ranged from 0.07 to 0.6. Positive effects of BCS on fertility have been reported in pasture and confinement dairy systems (Buckley et al., 2003; Roche et al., 2007; Santos et al., 2009). Similar findings have been reported in strain comparison studies using cows with New Zealand or North American ancestry (Horan et al., 2005a; Coleman et al., 2009). Holstein-Friesian cows of North American ancestry have lower BCS but greater milk

Table 6. The effect of genetic merit for fertility traits on mean PMNL counts of the uterus and proportion of cows classified with endometritis on wk 3 and 6 postpartum

\begin{tabular}{llllll}
\hline Genotype $^{2}$ & PMNL count $(\%)$ & $P$-value & OR $(95 \%$ CI $)$ & PP (SE) & $P$-value \\
\hline Wk 3 & & & & \\
Fert $-(\mathrm{n}=9)$ & $29.82(7.87-65.87)$ & 0.30 & $4.9(0.7,34.3)$ & $0.78(0.83)$ & 0.09 \\
Fert+ $(\mathrm{n}=12)$ & $13.97(1.77-37.79)$ & & 1.0 & $0.42(0.64)$ & \\
Wk 6 & & & & \\
Fert $-(\mathrm{n}=8)$ & $23.73(8.58-46.44)$ & 0.04 & $9.0(0.94,86.52)$ & $0.75(0.88)$ & 0.04 \\
Fert+ $(\mathrm{n}=8)$ & $3.91(0.00-15.36)$ & & 1.0 & $0.25(0.70)$ & \\
${ }^{1}$ OR = odds ratio; PP = predicted probability. & & \\
${ }^{2}$ Fert+ = good-fertility cows; Fert- = poor-fertility cows.
\end{tabular}


yield compared with Holstein-Friesian cows of New Zealand ancestry on a pasture-based system (Horan et al., 2005a; McCarthy et al., 2007). These strains were divergent in genetic merit for both milk production traits (greater in North American strain) and fertility traits (greater in New Zealand strain). The current study reports greater BCS in Fert+ cows compared with Fert-cows; the 2 groups have similar genetic merit for milk production traits but divergent genetic merit for fertility traits. Mean BCS loss from calving to nadir tended to be greater in Fert- cows than Fert+ cows, even though milk production was greater for Fert+ cows and both groups had similar nutritional management. The results of the current study are supported by the findings of Cummins et al. (2012a), and indicate that greater genetic merit for fertility traits supports a higher threshold BCS. Buckley et al. (2003) also reported a positive association between BCS and milk production. Together, these data suggest that the ability of Fert+ cows to maintain greater milk production and BCS profiles compared with Fert- cows is linked to greater postpartum DMI. Earlier recoupling of the somatotropic axis in Fert+ cows would facilitate the maintenance of greater BCS, while also maintaining greater milk production compared with Fert- cows (Cummins et al., 2012a,c).

\section{Uterine Health}

After calving, the uterus is exposed to microbial pathogens. The development and severity of uterine infection depends on the species of bacteria involved and their prevalence, as well as the immune response of the cow (Sheldon, 2004). Delayed clearance of uterine infection has serious consequences for reproductive performance (LeBlanc et al., 2002; Williams et al., 2005; McDougall et al., 2007, 2011). The mechanisms responsible may include altered follicle development and function (Sheldon et al., 2002), delayed resumption of cyclicity (Galvão et al., 2010), altered follicle steroidogenesis (Green et al., 2011), and development of a smaller corpus luteum (Williams et al., 2007). Both genotypes were managed as one group in the same housing, and would theoretically have been exposed to the same bacteria during the peripartum period. Uterine health was assessed by scoring vaginal mucus weekly, which reflects the level of bacterial contamination (Williams et al., 2005), and by classifying cows as having endometritis based on the proportion of PMNL in uterine cytology samples. At wk 1, both genotypes had a similar vaginal mucus score. Thereafter, Fertcows had greater vaginal mucus scores, indicating a slower clearance of bacterial contamination compared with Fert+ cows. Neutrophils enter the uterus from blood in response to chemokines, killing bacteria by phagocytosis (Sheldon, 2004). The Fert- cows tended to have increased odds of being classified as having endometritis based on PMNL population at wk 3 compared with Fert+ cows. By wk 6, a similar proportion of Fert- cows were classified as having endometritis but Fert+ cows had made a substantial recovery. The results of this study clearly indicate that genetic merit for fertility traits affects postpartum uterine health, which may be a result of differences in the function of the immune system. Differences in the metabolic status are potential mediators of immune function in dairy cows (Ingvartsen and Moyes, 2013). Hammon et al. (2006) reported impaired PMNL function, lower DMI, and greater NEFA and BHBA concentrations during the peripartum period in cows diagnosed with metritis or subclinical endometritis compared with healthy cows. Glucose, glutamine, NEFA, and BHBA are major energy sources for immune cells (Ingvartsen and Moyes, 2013). Although circulating NEFA and BHBA were similar between Fert+ and Fert- cows, DMI, energy balance at wk 1, and circulating glucose concentrations were greater in Fert + cows, suggesting Fert + cows had more glucose available in support of PMNL function.

\section{Resumption of Cyclicity}

Previous studies examining the resumption of ovarian cyclicity have reported positive (Galvão et al., 2010) and negative (Horan et al., 2005b) associations with fertility. Our results show that early resumption of cyclicity is associated with genetic merit for good fertility, which suggests that it is a positive fertility parameter. The interval from calving to resumption of cyclicity depends on the restitution of frequent luteinizing hormone pulses from the anterior pituitary, which has been reported to be negatively associated with energy balance (Canfield and Butler, 1990). Greater energy balance at wk 1, combined with greater concentrations of insulin and IGF-I, may have supported earlier ovulation in Fert+ cows (Butler et al., 2006).

\section{CONCLUSIONS}

Genetic merit for fertility traits had a significant effect on DMI, metabolic status, uterine health, and the resumption of postpartum cyclicity in cows with similar genetic merit for milk production and proportion of Holstein genetics that were exposed to the same management, nutrition, and environment. The Fert+ cows had greater DMI, energy balance at wk 1, circulating insulin, and IGF-I and glucose concentrations, maintained greater BCS, had superior uterine health, and showed an earlier resumption of cyclicity, while also 
achieving greater milk production. These results may explain, at least in part, the differences in reproductive performance reported in this genetic model.

\section{ACKNOWLEDGMENTS}

The authors thank J. P. Murphy, F. Coughlan, and the Moorepark (Fermoy, Ireland) farm staff for management and care of the cows enrolled on this study. Excellent technical assistance of J. Kenneally (Teagasc Moorepark) is acknowledged. The authors thank L. J. Spicer (Oklahoma State University, Stillwater) for assistance with establishment of the IGF-I iodination and radioimmunoassay procedures and $\mathrm{A}$. F. Parlow of the National Hormone and Peptide Program (NHPP; Torrance, CA) for supplying the anti-hIGF-1 used in the IGF-I RIA, NHPP-NIDDK. Funding from the Teagasc Walsh Fellowship Scheme, the National Development Plan and the Dairy Levy Trust is gratefully acknowledged.

\section{REFERENCES}

Bello, N. M., J. S. Stevenson, and R. J. Tempelman. 2012. Invited review: Milk production and reproductive performance: Modern interdisciplinary insights into an enduring axiom. J. Dairy Sci. 95:5461-5475.

Berry, D. P., J. R. Roche, and M. P. Coffey. 2008. Body condition score and fertility - More than just a feeling. Pages 107-118 in Fertility in Dairy Cows: Bridging the Gaps. M. D. Royal, N. C. Friggens, and R. F. Smith, ed. British Society of Animal Science/ Cambridge University Press, Cambridge, UK.

Buckley, F., K. O'Sullivan, J. F. Mee, R. D. Evans, and P. Dillon. 2003. Relationships among milk yield, body condition, cow weight, and reproduction in spring-calved Holstein-Friesians. J. Dairy Sci. 86:2308-2319.

Butler, S. T., A. L. Marr, S. H. Pelton, R. P. Radcliff, M. C. Lucy, and W. R. Butler. 2003. Insulin restores GH responsiveness during lactation-induced negative energy balance in dairy cattle: Effects on expression of IGF-I and GH receptor 1A. J. Endocrinol. 176:205-217.

Butler, S. T., S. H. Pelton, and W. R. Butler. 2006. Energy balance, metabolic status, and the first postpartum ovarian follicle wave in cows administered propylene glycol. J. Dairy Sci. 89:2938-2951.

Butler, W. R. 2003. Energy balance relationships with follicular development, ovulation and fertility in postpartum dairy cows. Livest. Sci. 83:211-218.

Butler, W. R., and R. D. Smith. 1989. Interrelationships between energy balance and postpartum reproductive function in dairy cattle. J. Dairy Sci. 72:767-783.

Canfield, R. W., and W. R. Butler. 1990. Energy balance and pulsatile LH secretion in early postpartum dairy cattle. Domest. Anim. Endocrinol. 7:323-330.

Coleman, J., K. M. Pierce, D. P. Berry, A. Brennan, and B. Horan. 2009. The influence of genetic selection and feed system on the reproductive performance of spring-calving dairy cows within future pasture-based production systems. J. Dairy Sci. 92:5258-5269.

Cummins, S. B., P. Lonergan, A. C. O. Evans, D. P. Berry, R. D. Evans, and S. T. Butler. 2012a. Genetic merit for fertility traits in Holstein cows: I. Production characteristics and reproductive efficiency in a pasture-based system. J. Dairy Sci. 95:1310-1322.

Cummins, S. B., P. Lonergan, A. C. O. Evans, and S. T. Butler. 2012b. Genetic merit for fertility traits in Holstein cows: II. Ovarian fol- licular and corpus luteum dynamics, reproductive hormones, and estrus behavior. J. Dairy Sci. 95:3698-3710.

Cummins, S. B., S. M. Waters, A. C. O. Evans, P. Lonergan, and S. T. Butler. 2012c. Genetic merit for fertility traits in Holstein cows: III. Hepatic expression of somatotropic axis genes during pregnancy and lactation. J. Dairy Sci. 95:3711-3721.

Darwash, A. O., G. E. Lamming, and J. A. Woolliams. 1997. The phenotypic association between the interval to post-partum ovulation and traditional measures of fertility in dairy cattle. Anim. Sci. 65:9-16.

Drackley, J. K. 1999. Biology of dairy cows during the transition period: The final frontier? J. Dairy Sci. 82:2259-2273.

Edmonson, A. J., I. J. Lean, L. D. Weaver, T. Farver, and G. Webster. 1989. A body condition scoring chart for Holstein dairy cows. J. Dairy Sci. 72:68-78.

Friggens, N. C., P. Berg, P. Theilgaard, I. R. Korsgaard, K. L. Ingvartsen, P. Løvendahl, and J. Jensen. 2007. Breed and parity effects on energy balance profiles through lactation: Evidence of genetically driven body energy change. J. Dairy Sci. 90:5291-5305.

Galvão, K. N., M. Frajblat, W. R. Butler, S. B. Brittin, C. L. Guard, and R. O. Gilbert. 2010. Effect of early postpartum ovulation on fertility in dairy cows. Reprod. Domest. Anim. 45:e207-e211.

Garverick, H. A., M. N. Harris, R. Vogel-Bluel, J. D. Sampson, J. Bader, W. R. Lamberson, J. N. Spain, M. C. Lucy, and R. S. Youngquist. 2013. Concentrations of nonesterified fatty acids and glucose in blood of periparturient dairy cows are indicative of pregnancy success at first insemination. J. Dairy Sci. 96:181-188.

Goldhawk, C., N. Chapinal, D. M. Veira, D. M. Weary, and M. A. G. von Keyserlingk. 2009. Prepartum feeding behavior is an early indicator of subclinical ketosis. J. Dairy Sci. 92:4971-4977.

Green, M. P., A. M. Ledgard, S. E. Beaumont, M. C. Berg, K. P. McNatty, A. J. Peterson, and P. J. Back. 2011. Long-term alteration of follicular steroid concentrations in relation to subclinical endometritis in postpartum dairy cows. J. Anim. Sci. 89:3551-3560.

Hammon, D. S., I. M. Evjen, T. R. Dhiman, J. P. Goff, and J. L. Walters. 2006. Neutrophil function and energy status in Holstein cows with uterine health disorders. Vet. Immunol. Immunopathol. 113:21-29.

Heins, B. J., L. B. Hansen, A. R. Hazel, A. J. Seykora, D. G. Johnson, and J. G. Linn. 2012. Short communication: Jersey $\times$ Holstein crossbreds compared with pure Holsteins for body weight, body condition score, fertility, and survival during the first three lactations. J. Dairy Sci. 95:4130-4135.

Horan, B., P. Dillon, P. Faverdin, L. Delaby, F. Buckley, and M. Rath. 2005a. The interaction of strain of Holstein-Friesian cows and pasture-based feed systems on milk yield, body weight, and body condition score. J. Dairy Sci. 88:1231-1243.

Horan, B., J. F. Mee, P. O'Connor, M. Rath, and P. Dillon. 2005 b. The effect of strain of Holstein-Friesian cow and feeding system on postpartum ovarian function, animal production and conception rate to first service. Theriogenology 63:950-971.

Huzzey, J. M., D. M. Veira, D. M. Weary, and M. A. G. von Keyserlingk. 2007. Prepartum behavior and dry matter intake identify dairy cows at risk for metritis. J. Dairy Sci. 90:3220-3233.

Ingvartsen, K. L. 2006. Feeding- and management-related diseases in the transition cow: Physiological adaptations around calving and strategies to reduce feeding-related diseases. Anim. Feed Sci. Technol. 126:175-213.

Ingvartsen, K. L., and K. Moyes. 2013. Nutrition, immune function and health of dairy cattle. Animal 7(Suppl. 1):112-122.

Jarrige, J. 1989. In INRAtion v. 2.7: Microsoft computer program of ration formulation for ruminant livestock. J. Agabriel, P. Champciaux, and C. Espinasse, ed. Centre National d'Études et de Ressources en Technologie Advancée (CNERTA), Dijon, France.

Leblanc, S. 2010. Assessing the association of the level of milk production with reproductive performance in dairy cattle. J. Reprod. Dev. 56(Suppl.):S1-S7.

LeBlanc, S. J. 2012. Interactions of metabolism, inflammation, and reproductive tract health in the postpartum period in dairy cattle. Reprod. Domest. Anim. 47:18-30. 
LeBlanc, S. J., T. F. Duffield, K. E. Leslie, K. G. Bateman, G. P. Keefe, J. S. Walton, and W. H. Johnson. 2002. Defining and diagnosing postpartum clinical endometritis and its impact on reproductive performance in dairy cows. J. Dairy Sci. 85:2223-2236.

Lucy, M. C. 2001. Reproductive loss in high-producing dairy cattle: Where will it end? J. Dairy Sci. 84:1277-1293.

Lucy, M. C., G. A. Verkerk, B. E. Whyte, K. A. Macdonald, L. Burton, R. T. Cursons, J. R. Roche, and C. W. Holmes. 2009. Somatotropic axis components and nutrient partitioning in genetically diverse dairy cows managed under different feed allowances in a pasture system. J. Dairy Sci. 92:526-539.

Maltz, E., L. F. Barbosa, P. Bueno, L. Scagion, K. Kaniyamattam, L. F. Greco, A. De Vries, and J. E. P. Santos. 2013. Effect of feeding according to energy balance on performance, nutrient excretion, and feeding behavior of early lactation dairy cows. J. Dairy Sci. 96:5249-5266.

McCarthy, S., D. P. Berry, P. Dillon, M. Rath, and B. Horan. 2007. Influence of Holstein-Friesian strain and feed system on body weight and body condition score lactation profiles. J. Dairy Sci. 90:1859-1869.

McDougall, S., H. Hussein, D. Aberdein, K. Buckle, J. Roche, C. Burke, M. Mitchell, and S. Meier. 2011. Relationships between cytology, bacteriology and vaginal discharge scores and reproductive performance in dairy cattle. Theriogenology 76:229-240.

McDougall, S., R. Macaulay, and C. Compton. 2007. Association between endometritis diagnosis using a novel intravaginal device and reproductive performance in dairy cattle. Anim. Reprod. Sci. 99:9-23.

Moyes, K. M., T. Larsen, and K. L. Ingvartsen. 2013. Generation of an index for physiological imbalance and its use as a predictor of primary disease in dairy cows during early lactation. J. Dairy Sci. 96:2161-2170

Nebel, R. L., and M. L. McGilliard. 1993. Interactions of high milk yield and reproductive performance in dairy cows. J. Dairy Sci. $76: 3257-3268$

O'Mara, F. P. 1997. A Net Energy System for Cattle and Sheep. Department of Animal Science and Production, Faculty of Agriculture, University College Dublin, Belfield, Dublin, Ireland.

Oetzel, G. R. 2004. Monitoring and testing dairy herds for metabolic disease. Vet. Clin. North Am. Food Anim. Pract. 20:651-674

Patton, J., D. A. Kenny, S. McNamara, J. F. Mee, F. P. O'Mara, M. G. Diskin, and J. J. Murphy. 2007. Relationships among milk production, energy balance, plasma analytes, and reproduction in Holstein-Friesian cows. J. Dairy Sci. 90:649-658.

Patton, J., J. J. Murphy, F. P. O'Mara, and S. T. Butler. 2008. A comparison of energy balance and metabolic profiles of the New Zealand and North American strains of Holstein Friesian dairy cow. Animal 2:969-978.

Pollott, G. E., and M. P. Coffey. 2008. The effect of genetic merit and production system on dairy cow fertility, measured using progesterone profiles and on-farm recording. J. Dairy Sci. 91:3649-3660.

Prendiville, R., K. M. Pierce, and F. Buckley. 2009. An evaluation of production efficiencies among lactating Holstein-Friesian, Jersey, and Jersey $\times$ Holstein-Friesian cows at pasture. J. Dairy Sci. 92:6176-6185
Roche, J. R., D. P. Berry, and E. S. Kolver. 2006. Holstein-Friesian strain and feed effects on milk production, body weight, and body condition score profiles in grazing dairy cows. J. Dairy Sci. 89:3532-3543.

Roche, J. R., D. Blache, J. K. Kay, D. R. Miller, A. J. Sheahan, and D. W. Miller. 2008. Neuroendocrine and physiological regulation of intake with particular reference to domesticated ruminant animals. Nutr. Res. Rev. 21:207-234.

Roche, J. R., K. A. Macdonald, C. R. Burke, J. M. Lee, and D. P. Berry. 2007. Associations among body condition score, body weight, and reproductive performance in seasonal-calving dairy cattle. J. Dairy Sci. 90:376-391

Santos, J. E. P., H. M. Rutigliano, and M. F. S. Filho. 2009. Risk factors for resumption of postpartum estrous cycles and embryonic survival in lactating dairy cows. Anim. Reprod. Sci. 110:207-221.

SAS Institute. 2006. SAS User's Guide: Statistics. SAS Institute Inc. Cary, NC.

Sepúlveda-Varas, P., J. M. Huzzey, D. M. Weary, and M. A. G. Von Keyserlingk. 2013. Behaviour, illness and management during the periparturient period in dairy cows. Anim. Prod. Sci. 53:988-999.

Sheldon, I. M. 2004. The postpartum uterus. Vet. Clin. North Am. Food Anim. Pract. 20:569-591.

Sheldon, I. M., J. Cronin, L. Goetze, G. Donofrio, and H.-J. Schuberth. 2009. Defining postpartum uterine disease and the mechanisms of infection and immunity in the female reproductive tract in cattle. Biol. Reprod. 81:1025-1032.

Sheldon, I. M., G. S. Lewis, S. LeBlanc, and R. O. Gilbert. 2006. Defining postpartum uterine disease in cattle. Theriogenology 65:1516-1530.

Sheldon, I. M., D. E. Noakes, A. N. Rycroft, D. U. Pfeiffer, and H. Dobson. 2002. Influence of uterine bacterial contamination after parturition on ovarian dominant follicle selection and follicle growth and function in cattle. Reproduction 123:837-845.

Taylor, V. J., Z. Cheng, P. G. A. Pushpakumara, D. C. Wathes, and D. E. Beever. 2004. Relationships between the plasma concentrations of insulin-like growth factor-I in dairy cows and their fertility and milk yield. Vet. Rec. 155:583-588.

Veerkamp, R. F., B. Beerda, and T. van der Lende. 2003. Effects of genetic selection for milk yield on energy balance, levels of hormones, and metabolites in lactating cattle, and possible links to reduced fertility. Livest. Sci. 83:257-275.

Villa-Godoy, A., T. L. Hughes, R. S. Emery, L. T. Chapin, and R. L. Fogwell. 1988. Association between energy balance and luteal function in lactating dairy cows. J. Dairy Sci. 71:1063-1072.

Wathes, D. C. 2012. Mechanisms linking metabolic status and disease with reproductive outcome in the dairy cow. Reprod. Domest. Anim. 47:304-312.

Williams, E. J., D. P. Fischer, D. E. Noakes, G. C. W. England, A. Rycroft, H. Dobson, and I. M. Sheldon. 2007. The relationship between uterine pathogen growth density and ovarian function in the postpartum dairy cow. Theriogenology 68:549-559.

Williams, E. J., D. P. Fischer, D. U. Pfeiffer, G. C. W. England, D. E. Noakes, H. Dobson, and I. M. Sheldon. 2005. Clinical evaluation of postpartum vaginal mucus reflects uterine bacterial infection and the immune response in cattle. Theriogenology 63:102-117. 